\title{
PENANGANAN PELANGGARAN HAM OLEH KANTOR WILAYAH KEMENTERIAN HUKUM DAN HAM NUSA TENGGARA TIMUR MELALUI PELAYANAN KOMUNIKASI MASYARAKAT
}

(Human Rights Violation Settlement by Regional Office of Ministry of Law and Human Rights In Nusa Tenggara Timur Province through Public Communication Service)

\author{
Solidaman Bertho Plaituka \\ Pegawai Kantor Wilayah Kementerian Hukum dan HAM NTT \\ Jl. W.J. Lalamentik No.98, Oebobo, Kota Kupang, Nusa Tenggara Timur \\ Email: soliplaituka@gmail.com
}

Naskah diterima: 15 Maret 2017; revisi: 18 April 2017; disetujui: 16 Mei 2017

\begin{abstract}
Abstrak
Saat ini terdapat banyak dugaan pelanggaran HAM di Provinsi Nusa Tenggara Timur baik secara vertikal yang dilakukan oleh Pemerintah maupun secara horizontal yang dilakukan oleh sesama masyarakat. Hal ini ditandai dengan tingginya pengaduan masyarakat yang masuk ke tim Pelayanan Komunikasi Masyarakat pada Kantor Wilayah Kementerian Hukum dan HAM NTT. Yankomas merupakan sarana untuk menyelesaikan dugaan pelanggaran HAM yang terjadi di masyarakat yang dimandatkan oleh Perpres Nomor 75 Tahun 2015 tentang Rencana Aksi Nasional Hak Asasi Manusia 2015-2019. Penulis menggunakan metode penelitian hukum empiris berkaitan dengan pendekatan statute approach dan cases approach. Pada tahun 2016 terdapat 50 (lima puluh) permasalahan yang dikomunikasikan kepada Tim Pelayanan Komunikasi Masyarakat Kantor Wilayah Kementerian Hukum dan HAM NTT yaitu 25 pengaduan lisan/konsultasi dan 25 pengaduan secara tertulis. Peran Yankomas dalam menyelesaikan dugaan pelanggaran HAM ini memuaskan pengadu karena semua pengaduan yang masuk mendapat penyelesaian ataupun penjelasan secara baik. Penyelesaian yang dilakukan dengan mengundang pihak terlapor dan stakeholder terkait lainnya dalam sebuah rapat koordinasi yang didalamnya dicarikan solusi dan jalan keluar terhadap masalah yang diadukan. Pelayanan Komunikasi Masyarakat hendaknya terus dikembangkan mengingat tingginya angka pengaduan masyarakat yang mulai menyadari bahwa terdapat peran negara untuk melakukan perlindungan,pemajuan penegakan Hak Asasi Manusia.
\end{abstract}

Kata Kunci: pelayanan komunikasi masyarakat, pengaduan masyarakat, pelanggaran HAM

\begin{abstract}
Currently, there are many human rights violation allegations in Nusa Tenggara Timur either done vertically by Government or horizontally by the society. High number of complaints received by the People Communication Service (Yankomas) team in the Regional Office of Ministry of Law in Nusa Tenggara Timur (NTT) and Human Rights indicates this phenomenon. Yankomas is tool to settle human rights violation allegation that has its legal ground on the Presidential Regulation Number 75 Year 2015 about National Human Rights Action Plan 2015-2019. This writing uses empirical research method with statute approach and cases approach. In 2016, there were 50 complaints followed up by the People Communication Service team in the Regional Office of Ministry of Law in NTT comprises 25 verbal complaints/consultation and 25 written complaints. Yankomas role in settle down this complaints had satisfied the complainant since all complaints were taken care well. The settlement were conducted by inviting both the complainants and other stakeholders in a coordination meeting to find a solution. The People Communication Service need to be developed more considering the high number of reports comes from the society which starts to realize that there is role of the state to protect and develop human rights.

Keywords: People Communication Service, public complaints, human rights violation
\end{abstract}




\section{A. Pendahuluan}

Lahirnya konstitusi atau Undang-Undang Dasar merupakan akibat munculnya gagasan demokrasi konstitusional yang menyatakan bahwa pemerintahan yang demokratis adalah pemerintahan yang terbatas kekuasaanya dan tidak dibenarkan bertindak sewenang-wenang terhadap warga negaranya. Negara yang konstitusional digambarkan sebagai lembaga negara dengan fungsi normatif tertentu, yakni perlindungan bagi hak-hak asasi manusia, serta pengendalian dan pengaturan kekuasaan ${ }^{1}$. Hak Asasi manusia ini harus dijunjung tinggi oleh setiap Negara melalui Konstitusinya. Maka dari itu Negara Indonesia mengatur secara khusus dalam Undang- Undang Dasar 1945.

Hak Asasi Manusia merupakan seperangkat hak yang melekat pada setiap individu sejak dalam kandungan sebagai Anugerah Tuhan Yang Maha Esa, bersifat universal dan abadi sehingga wajib dihormati, dijunjung tinggi dan dilindungi oleh Negara, hukum, pemerintah serta setiap orang ${ }^{2}$. Hak asasi manusia merupakan hak dasar yang secara kodrati melekat pada diri manusia, bersifat universal dan langgeng, oleh karena itu harus dilindungi, dihormati, dipertahankan, dan tidak boleh diabaikan, dikurangi, atau dirampas oleh siapapun. Disamping memiliki Hak Asasi Manusia, maka setiap individu juga memiliki Kewajiban Asasi Manusia (KAM). Kewajiban Asasi Manusia merupakan seperangkat kewajiban yang apabila tidak dilaksanakan, tidak memungkinkan terlaksananya dan tegaknya Hak Asasi Manusia.
Perlindungan, penegakan, penghormatan dan pemajuan HAM dimaksudkan untuk meningkatkan harkat dan martabat manusia. Oleh karena itu Indonesia sebagai anggota Perserikatan Bangsa-Bangsa mengemban tanggung jawab moral dan hukum untuk menjunjung tinggi dan melaksanakan Deklarasi Universal tentang Hak Asasi Manusia yang ditetapkan oleh Perserikatan Bangsa-Bangsa, serta berbagai instrumen internasional lainnya mengenai hak asasi manusia yang telah diterima oleh negara Republik Indonesia.

Di Nusa Tenggara Timur sendiri banyak terjadi dugaan pelanggaran HAM baik itu secara vertikal yang dilakukan Pemerintah maupun secara horizontal yang dilakukan oleh sesama masyarakat. Hal ini dipengaruhi oleh 2 faktor utama yaitu faktor internal dan eksternal. Faktor internal meliputi: Sifat egoisme individu yang menyebabkan seseorang memiliki hasrat yang besar untuk mencapai sesuatu yang diinginkan sehingga menghalalkan segala cara agar haknya terpenuhi walau caranya bisa melanggar hak orang lain; Tingkat kesadaran HAM yang masih rendah dimana ada yang sangat menghargai HAM dan ada juga yang sangat mengabaikan adanya HAM tersebut. Dan sikap tidak toleran yang mengakibatkan munculnya rasa saling tidak menghormati dan menghargai atas keberadaan orang lain. Seakan-akan kedudukan seseorang direndahkan dan dilecehkan. Pada akhirnya sikap ini akan menjerumuskan seseorang untuk melakukan diskriminasi pada orang lain.

Sedangkan faktor eksternal penyebab terjadinya pelanggaran HAM antara lain disebabkan: 
1) Penyalahgunaan kekuasaan yang ada di lingkungan keluarga, masyarakat atau pun dilingkungan bangsa dan negara. Kekuasaan tidak selalu mengarah pada kekuasaan pemerintah, namun dalam bentuk kekuasaan lain salah satunya kekuasaan di sebuah perusahaan. Para pengusaha yang tidak memperdulikan hak-hak buruhnya jelas melanggar HAM. Dapat kita nyatakan bahwa setiap kekuasaan yang disalahgunakan akan mendorong timbulnya pelanggaran HAM.

2) Ketidaktegasan aparat penegak hukum. Aparat penegak hukum yang tidak tegas akan mengakibatkan timbulnya banyak pelanggaran HAM yang akan terjadi. Kasus pelanggaran HAM yang tidak diselesaikan secara tuntas tentu menjadi pemicu aksi pelanggaran HAM lain yang mungkin lebih merugikan. Aparat penegak hukum yang semena-mena dalam mengambil keputusan juga merupakan bentuk pelanggaran HAM dan menjadi contoh tidak baik, hal ini juga dapat menjadi pemicu terjadinya bentuk pelanggaran HAM lainnya.

3) Kesenjangan sosial dan ekonomi yang tinggi, ketidakseimbangan dan ketidakmerataan gaya hidup sudah mulai muncul di era saat ini. Perbedaan tingkat kekayaan atau jabatan yang dimiliki seseorang menjadi pemicu kesenjangan sosial dan ekonomi. Jika dibiarkan, bukan tidak mungkin akan banyak terjadi pelanggaran HAM seperti perampokan, perbudakan, pelecehan bahkan pembunuhan.

Di era reformasi saat ini perhatian Pemerintah terhadap demokrasi dan HAM merupakan pekerjaan yang amat berat karena Pemerintah dituntut untuk dapat menyelesaikan pelanggaran- pelanggaran HAM yang terjadi di masyarakat. Oleh karenanya Pemerintah melalui Undang- Undang Nomor 39 Tahun 1999 tentang Hak Asasi Manusia yang dijabarkan melalui Perpres Nomor 75 Tahun 2015 tentang Rencana Aksi Nasional Hak Asasi Manusia 2015-2019 untuk ruang pelayanan komunikasi masyarakat $^{3}$ dengan tujuan menyelesaikan setiap perbuatan yang dilakukan oleh seseorang, kelompok orang, aparat Negara, dan instansi/lembaga pemerintah baik disengaja maupun tidak disengaja atau kelalaian yang secara melawan hukum meliputi mengurangi, menghalangi, membatasi dan / atau mencabut Hak Asasi Manusia sesorang atau kelompok orang yang dijamin oleh Undang- Undang dan tidak mendapat atau dikhawatirkan tidak akan memperoleh penyelesaian hukum yang adil dan benar sesuai dengan ketentuan peraturan perundang- undangan.

Kantor Wilayah Kementerian Hukum dan Hak Asasi Manusia Nusa Tenggara Timur selaku perpanjangan tangan Pemerintah Pusat di daerah melaksanakan tugas pembantuan Hukum dan HAM dan salah satu tugas yang dilaksanakan adalah membuka ruang Pelayanan Komunikasi Masyarakat. Terdapat beberapa permasalahan yang menonjol sepanjang tahun ini yaitu ketidakpuasan terhadap aparat, kekerasan dalam rumah tangga, pertanahan, dan trafficking. Berdasarkan uraian di atas maka terdapat beberapa masalah yaitu 1). Bagaimana ruang lingkup kerja dan tata cara penyelesaian dugaan pelanggaran HAM yang

Peraturan Presiden Nomor 75 Tahun 2015 tentang Rencana Aksi Nasional Hak Asasi Manusia 2015-2019 salah satu strategi yang harus dijalankan adalah Pelayanan Komunikasi Masyarakat. 
terjadi di Masyarakat?; 2). Bagaimana capaian dan pemetaan penanganan kasus dugaan pelanggaran HAM melalui wadah Pelayanan Komunikasi Masyarakat?

\section{B. Metode Penelitian}

Dalam penyelesaian tulisan ini Penulis menggunakan metode penelitian hukum empiris berkaitan dengan fenomena dan kenyaataan yang terjadi di lapangan terutama yang dihadapi oleh Anggota Tim Pelayanan Komunikasi Masyarakat Kanwil Kemenkumham NTT dalam menghadapi pemasalahan pelanggaran HAM. Lokasi Penelitian bertempat pada Kantor Wilayah Kementerian Hukum dan HAM NTT di Kupang. Dalam penulisan pendekatan digunakan adalah": Pendekatan Statute Approach yakni pendekatan yang dilakukan dengan menggunakan peraturan perundang- undangan yang berkaitan dengan masalah yang diteliti yaitu Peraturan Presiden Nomor 75 Tahun 2015 tentang Rencana Aksi Nasional Hak Asasi Manusia 2015-2019 dan Peraturan Menteri Hukum dan HAM Nomor 23 Tahun 2013 tentang Pelayanan Komunikasi Masyarakat. Dan pendekatan Cases Approach yakni pendekatan yang dilakukan melalui kasuskasus yang ada dan dihadapi yang berkaitan dengan masalah yang diteliti.

\section{Pembahasan}

\section{Tata Cara Penyelesaian Dugaan Pelanggaran HAM}

Pelayanan Komunikasi Masyarakat yang selanjutnya disebut Yankomas adalah pemberian layanan terhadap masyarakat tentang adanya dugaan permasalahan hak asasi manusia yang dikomunikasikan maupun yang tidak/belum dikomunikasikan oleh seseorang atau kelompok orang. Dalam melaksanaakan tugasnya dibentuklah Tim Pelayanan Komunikasi Masyarakat yang dijalankan oleh Kanwil Kementerian Hukum dan HAM di bawah bidang Hak Asasi Manusia. Fungsi ini dalam keseharian dijalankan pada Sub Bidang Pelayanan, Pengkajian dan Informasi HAM.

Ruang lingkup Pelayanan Komunikasi masyarakat adalah setiap perbuatan yang dilakukan oleh seseorang, kelompok orang, aparat negara, dan instansi/lembaga pemerintah baik disengaja maupun tidak disengaja atau kelalaian yang secara melawan hukum meliputi mengurangi, menghalangi; membatasi; dan/ atau mencabut,hak asasi manusia seseorang atau kelompok orang yang dijamin oleh Undang-Undang, dan tidak mendapatkan atau dikhawatirkan tidak akan memperoleh penyelesaian hukum yang adil dan benar sesuai dengan ketentuan peraturan perundangundangan. Ketentuan diatas dikecualikan terhadap kasus yang sedang dalam proses hukum di peradilan tingkat pertama, tingkat banding, atau tingkat kasasi; dan pelanggaran hak asasi manusia berat sesuai dengan ketentuan peraturan perundang-undangan.

Tugas dan Fungsi Tim Pelayanan Komunikasi Masyarakat ${ }^{5}$ meliputi yankomas Yang dikomunikasikan yakni secara lisan maupun tulisan. Dan yankomas yang tidak dikomunikasikan yakni berkaitan dengan 
fenomena di masyarakat, bersifat kasuistik dan Kebutuhannya mendesak.

Dalam pelaksanaanya setiap pengaduan ditindaklanjuti baik itu lisan maupun tulisan dengan terlebih dahulu dilakukan penelaahan terhadap pengaduan dimaksud. Telaahan ini bertujuan menemukan dugaan pelanggaran HAM yang ada dalam setiap pengaduan yang masuk. Hasil telaahan ini dibuat dalam bentuk format analisis dugaan pelanggaran HAM yang terjadi dan rekomendasi terkait pengaduan dimaksud yang ditandatangani oleh analis permasalahan HAM, Kepala Sub Bidang Pelayanan Pengkajian dan Informasi HAM dan diketahui oleh Kepala Bidang HAM. Untuk Komunikasi yang disampaikan secara langsung oleh Penyampai Komunikasi kepada Tim Yankomas harus mengisi formulir Komunikasi dan melampirkan dokumen pendukung seperti kartu identitas dan bukti-bukti lainnya yang dimiliki oleh penyampai komunikasi/pengadu.

Terkait dengan Yankomas yang Tidak/Belum Dikomunikasikan ${ }^{6}$ Tim yankomas melakukan identifikasi dugaan permasalahan hak asasi manusia yang tidak/belum dikomunikasikan. Identifikasi dugaan permasalahan hak asasi manusia dilakukan melalui pengumpulan data/ informasi yang berasal dari media cetak dan elektronik; instansi/lembaga pemerintah, organisasi, atau anggota masyarakat; dan/ atau pengamatan secara langsung ke lokasi terjadinya dugaan pelanggaran hak asasi manusia. Hasil identifikasi dugaan pelanggaran hak asasi manusia yang tidak/ belum dikomunikasikan dilakukan penelaahan. Penelaahan dimaksudkan untuk menentukan para pihak; waktu, tempat, dan kronologis terjadinya dugaan pelanggaran hak asasi manusia; hak asasi manusia yang dilanggar; dan instansi/lembaga pemerintah yang mempunyai kewenangan untuk menyelesaikan dugaan pelanggaran hak asasi manusia. Penelaahan harus mempertimbangkan aspek hukum dan hak asasi manusia. Hasil penelaahan harus memuat saran dan tindak lanjut penyelesaian pelanggaran hak asasi manusia.

Setelah mendapatkan hasil telaahan maka Tim Yankomas membuat Rapat Koordinasi Pelayanan Komunikasi Masyarakat setiap bulannya. Dalam Rapat ini akan diundang Tim terpadu yang terdiri dari Kepolisian Daerah Nusa Tenggara Timur, Kejaksaan Tinggi NTT, Pengadilan Tinggi Kupang, Biro Hukum Setda NTT, Ombudsman Perwakilan NTT, LSM Rumah Perempuan, LBH APIK dan stakeholder yang terkait dengan pengaduan yang disampaikan. Dalam rapat ini Tim akan berdiskusi dan menyampaikan masukan, saran dan informasi terkait dengan masalah yang diadukan. Kemudian dari hasil rapat ini kemudian akan dirumuskan sebuah rekomendasi tim secara terpadu yang akan disampaikan kepada pengadu dan teradu.

Rekomendasi ini kemudian akan diteruskan melalui surat yang ditandatangani oleh Kepaa Kantor Wilayah Kementerian Hukum dan HAM NTT. Surat Koordinasi paling sedikit memuat dugaan pelanggaran hak asasi manusia; nama jabatan dan/atau nama instansi/lembaga pemerintah yang berwenang untuk melakukan pelindungan dan pemenuhan hak asasi manusia; masukan bagi instansi/lembaga pemerintah; dan permintaan informasi perkembangan dan

6 Pasal 9, Ibid. 
penyelesaian dugaan pelanggaran hak asasi manusia.

Tim Yankomas melakukan pemantauan Surat Koordinasi yang telah disampaikan kepada instansi/lembaga pemerintah. Dalam hal instansi/lembaga pemerintah tidak menindaklanjuti Surat Koordinasi yang telah disampaikan oleh maka tim yankomas kembali menyampaikan Surat Koordinasi susulan I dan susulan II. Surat Koordinasi susulan disampaikan secara berkala setiap 2 (dua) bulan. Dalam hal atasan instansi/lembaga pemerintah tidak menindaklanjuti Surat Rekomendasi sampai dengan Surat Rekomendasi susulan II maka tim yankomas akan melaporkan kepada Direktorat Jenderal HAM untuk dimasukan dalam rapat Tim Yankomas di tingkat pusat melalui Direktorat Pelayanan Komunikasi Masyarakat. Tim yankomas pusat akan menyampaikan laporan kepada instansi/lembaga pemerintah pada tingkat pusat. Dalam hal laporan tidak ada penyelesaian, Panitia RANHAM Nasional melaporkan dugaan pelanggaran hak asasi manusia kepada Presiden.

Dalam menjalankan fungsi menerima pengaduan masyarakat Tim tidak dibekali dengan SOP sehingga atas inisiatif dari Kepala Bidang HAM maka dibuatlah SOP secara mandiri yang hanya diterapkan di lingkungan Kantor Wilayah Kementerian Hukum dan HAM NTT. Yang menjadi kendala utama dalam pelaksanaan tugas malayani pengaduan adalah keterbatasan saran dan prasarana yang ada dimana tim yankomas harus menggunakan fasilitas pribadi untuk bekerja. Tidak disediakannya fasilitas ini menjadi penghambat karena tugas dan fungsi yang dilaksanakan ini memerlukan sarana prasarana yang memadai guna melayani pengaduan warga masayarakat. Langkah yang dilakukan adalah setiap tahunnya tim membuat perencanaan untuk diajukan kepada biro perencanaan untuk diberikan tambahan sarana prasarana namun hingga saat ini belum ada realisasi yang memadai.

\section{Capaian dan pemetaan penanganan kasus dugaan pelanggaran HAM melalui wadah Pelayanan Komunikasi Masyarakat Tahun 2016.}

Yankomas yang dilaksanakan di Kanwil NTT sudah menjadi salah satu program andalan dari Kanwil Kemenkumham NTT. Hasil dari penilaian Kanwil terbaik tahun 2014 dalam rangka hari Dharma Karya Dhika Bidang HAM NTT mendapat peringkat 2 Nasional. Pengakuan dari Direktur Yankomas Ditjen Hak Asasi Manusia bahwa Yankomas terbaik itu ada di Kanwil NTT.

Pada tahun 2016 terdapat 50 (lima puluh) permasalahan yang dikomunikasikan kepada Tim Pelayanan Komunikasi Masyarakat yaitu 25 pengaduan lisan/konsultasi dan 25 pengaduan secara tertulis. Pada Triwulan I terdapat 21 pengaduan, Triwulan II sebanyak 6 pengaduan, Triwulan III sebanyak 14 pengaduan dan Triwulan IV sebanyak 8 pengaduan baik tertulis maupun lisan. 
Tabel 1. Pemetaan Pelayanan Komunikasi Masyarakat per Triwulan Tahun 2016

\begin{tabular}{|c|c|c|c|c|c|c|}
\hline NO & JENIS KASUS & TRIWULAN I & TRIWULAN II & TRIWULAN III & TRIWULAN IV & JUMLAH \\
\hline 1. & Trafficking & - & - & - & - & - \\
\hline 2. & $\begin{array}{l}\text { Ketidakpuasan terrhadap perilaku } \\
\text { aparat }\end{array}$ & 6 & 1 & 2 & 2 & 11 \\
\hline 3. & Penganiayaan & 1 & 1 & 4 & - & 6 \\
\hline 4. & KDRT & 3 & - & 4 & 1 & 8 \\
\hline 5. & Pemerkosaan/ Pelecehan Seksual & 1 & 1 & - & - & 2 \\
\hline 6. & $\begin{array}{l}\text { Penelelantaran Anak (Akibat IJM/ } \\
\text { Cerai) }\end{array}$ & 1 & - & - & 1 & 2 \\
\hline 7. & Ketenagakerjaan & 1 & - & - & 2 & 3 \\
\hline 8. & Ingkar Janji Menikah (IJM) & 3 & 1 & 3 & - & 7 \\
\hline 9. & Pertanahan & 2 & - & 1 & - & 3 \\
\hline 10. & Kepegawaian & 1 & 1 & - & - & 2 \\
\hline 11. & Hak Anak Atas Pendidikan & 1 & - & - & 2 & 3 \\
\hline 12 & Hak Asuh Anak & 1 & - & - & - & 1 \\
\hline 13. & Keterangan Palsu & - & 1 & - & - & 1 \\
\hline 14. & Kehutanan & - & - & - & 1 & 1 \\
\hline & Jumlah & 21 & 6 & 14 & 8 & 50 \\
\hline
\end{tabular}

Sumber: Data Primer Kantor Wilayah Kementerian Hukum dan HAM NTT

Tingginya pengaduan yang masuk ke tim Yankomas disebabkan oleh beberapa faktor yaitu:

1) Masyakarat semakin sadar akan Hak Asasi Manusia sehingga mereka berusaha memperjuangkan Hak tersebut. Apabila terjadi pelanggaran baik terhadap Hak Sipil, politik maupun Hak ekonomi, sosial dan budaya masyarakat selalu mencari wadah penyelesaian dan di daerah ada pada Kantor Wilayah Kementerian Hukum dan HAM.

2) Setiap pelaksanaan kegiatan di semua daerah selalu diselipkan informasi bahwa Kantor Wilayah Kementerian Hukum dan HAM NTT menyediakan Ruang Pelayanan Komunikasi Masyarakat terkait dugaan pelanggaran HAM.

3) Tingkat kepercayaan masyarakat terhadap tim yankomas semakin tinggi karena pengaduan yang masuk selalu diselesaikan dengan baik.

Grafik 1. Jenis Pengaduan

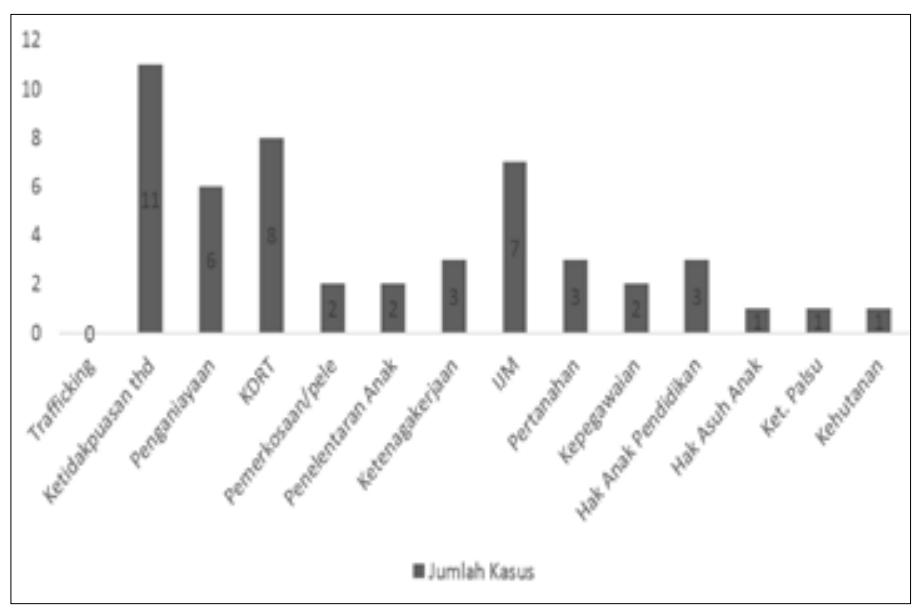

Sumber : Data Primer Kantor Wilayah Kementerian Hukum dan HAM NTT

Permasalahan yang paling banyak dikomunikasikan pada tahun 2016 yaitu 
ketidakpuasan terhadap aparat sebanyak 11 pengaduan yaitu 6 pengaduan tertulis dan 5 pengaduan lisan. Pengaduan terbanyak kedua yaitu Kekerasan Dalam Rumah Tangga sebanyak 8 pengaduan yang disampaikan baik secara lisan maupun tertulis masing-masing 4 kasus. Selain itu, kasus Ingkar Janji Menikah (IJM) juga sering dikomunikasikan yaitu sebanyak 7 pengaduan. Pengaduan Masyarakat yang masuk ke Unit Yankomas kemudian dikelompokkan berdasar jenis kasusnya, yaitu:

\section{1) Ketidakpuasan terhadap Aparat}

Permasalahan antara masyarakat dengan pemerintah terjadi karena ketidakpuasan masyarakat dalam menerima pelayanan yang diberikan pemerintah, antara lain pada institusi Kepolisian, Pengadilan Negeri Kupang dan Pengadilan Negeri Maumere. Kebanyakan masyarakat tidak puas karena perilaku aparat yang cenderung arogan dalam melayani masyarakat. Sikap overacting para aparat, sedikit banyak, merupakan turunan dari dokrin masa lalu yang menempatkan aparat hanya sebagai alat untuk menakuti-nakuti dan membungkam masyarakat. Aparat masih memosisikan diri sebagai penjaga tahta para penguasa, bukannya untuk melindungi masyarakat, serta menjaga ketertiban dan keamanan sosial?.
Grafik 2. Pemetaan Yankomas Kasus ketidakpuasan terhadap Aparat per Triwulan

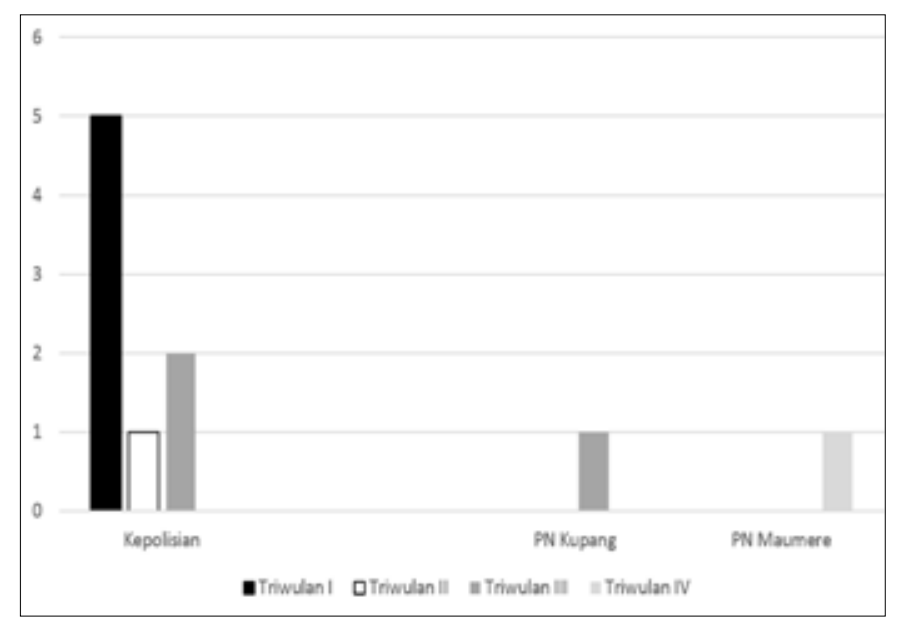

Sumber : Data Primer Kantor Wilayah Kementerian Hukum dan HAM NTT

Ketidakpuasan terhadap aparat kepolisian oleh masyarakat antara lain disebabkan laporan masyarakat ditolak aparat, perlakuan petugas yang tidak ramah kepada pelapor sehingga yang bersangkutan merasa dipermainkan, selain itu penanganan kasus yang dianggap terlalu lama sehingga menimbulkan kekhawatiran masyarakat bahwa permasalahan tersebut tidak ditangani. Namun setelah dikoordinasikan, pihak kepolisian mengklarifiasi permasalahan tersebut disebabkan laporan yang kurang lengkap baik bukti dan saksi maupun pelapor yang kurang kooperatif dalam memberikan keterangan, untuk kasus yang telah lama pihak kepolisian bersedia membantu memantau kasus yang dikomunikasikan agar segera ditangani secara baik.

Ketidakpuasan terhadap Pengadilan Negeri Kupang maupun merupakan kelanjutan dari hasil putusan pengadilan atas perkara pertanahan dimana terdapat tanah yang 
belum dieksekusi, hasil klarifikasi dengan pihak pengadilan diketahui bahwa putusan perkara tanah tersebut bersifat declaratoir (menyatakan) sehingga tidak bisa dilakukan eksekusi, untuk mengosongkan lahan yang telah diakui secara sah oleh pengadilan tersebut maka pelapor disarankan untuk mengajukan gugatan guna melakukan eksekusi. Terdapat juga pengaduan terkait eksekusi perkara yang menurut pelapor melanggar hak asasi manusia karena tidak mendapatkan pemberitahuan akan tetapi setelah diklarifikasi diketahui bahwa surat rencana eksekusi disampaikan kepada pelapor namun yang bersangkutan tidak pernah berada di rumah ketika petugas juru sita mengantarkan surat dimaksud sehingga diberikan kepada pihak kelurahan dimana pelapor berdomisili.

Ketidakpuasan terhadap Pengadilan Negeri Maumere juga berkaitan dengan eksekusi yang belum dilaksanakan dan permasalahan ini masih dalam proses koordinasi. Melihat permasalahan yang dikomunikasikan tersebut bahwa masyarakat membutuhkan pelayanan dari pemerintah yang lebih prima agar masyarakat dapat terlayani secara baik. Masyarakat juga perlu dibekali pengetahuan terhadap mekanisme yang terdapat dipemerintahan agar tidak timbul kekhawatiran terhadap penanganan yang diberikan oleh aparat pemerintah.

\section{2) Kekerasan Dalam Rumah Tangga (KDRT)}

Kekerasan dalam rumah tangga bisa dialami oleh perempuan, laki-laki maupun anakanak. Pada tahun 2016 terdapat 8 (delapan) kasus kekerasan dalam rumah tangga yang dikomunikasikan kepada Tim Pelayanan Pengaduan Masyarakat Kantor Wilayah Kementerian Hukum dan HAM NTT.
Grafik 3. Pelayanan Komunikasi Masyarakat Kasus KDRT per Triwulan Tahun 2016

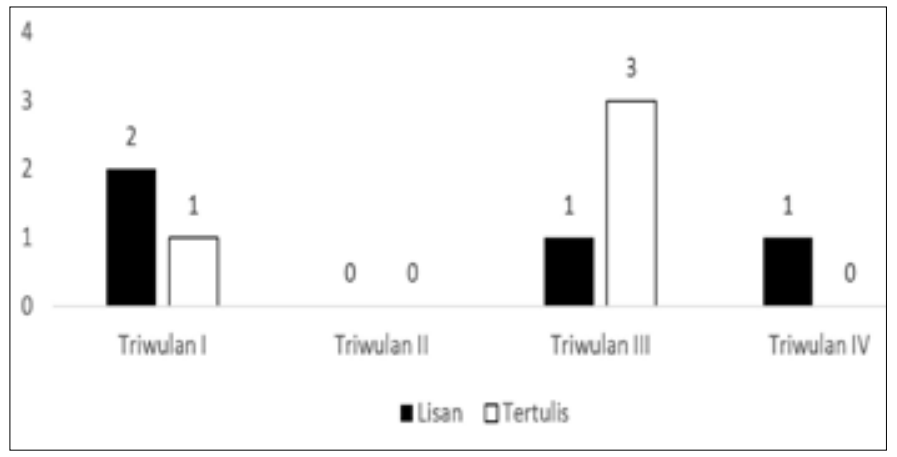

Sumber : Data Primer Kantor Wilayah Kementerian Hukum dan HAM NTT

Tahun 2016 pelaku kekerasan dalam rumah tangga didominasi oleh anggota Polisi dan Pegawai Negeri Sipil yang memiliki pendidikan dan kedudukan sosial yang baik di masyarakat. Selain itu terdapat juga terlapor adalah pensiunan Polri dan Kepala Desa. Upaya yang dilakukan Tim Pelayanan Komunikasi Masyarakat Kantor Wilayah Kementerian Hukum dan HAM NTT dalam penanganan pengaduan KDRT yaitu melakukan koordinasi dengan instansi terkait dalam hal ini instansi tempat para terlapor bekerja untuk ditindaklanjuti sesuai dengan kode etik dan juga pihak kepolisian daerah NTT untuk penyelesaian kasus pidananya.

Grafik 4. Pemetaan Yankomas Kasus KDRT Berdasarkan Pekerjaan Terlapor Tahun 2016

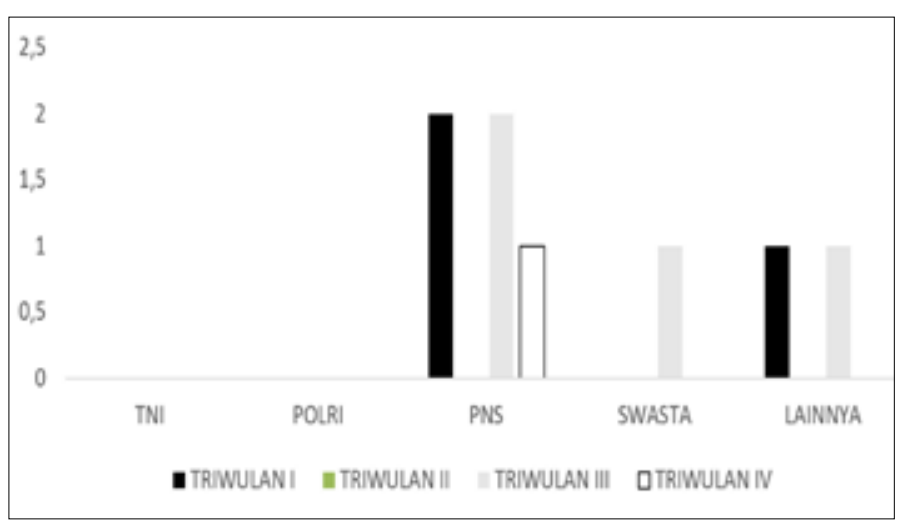

Sumber : Data Primer Kantor Wilayah Kementerian Hukum dan HAM NTT 
Terjadinya kekerasan dalam rumah tangga bermula dari adanya relasi kekuasaan yang timpang antara lelaki (suami) dengan perempuan (istri). Kondisi ini tidak jarang mengakibatkan tindak kekerasan oleh suami terhadap istrinya justru dilakukan sebagai bagian dari penggunaan otoritas yang dimilikinya. sebagai kepala keluarga. Justifikasi atas otoritas itu bisa lahir didukung oleh perangkat undangundang negara atau persepsi-persepsi sosial dalam bentuk mitos-mitos superioritas seorang laki-laki yang dipercayai masyarakat tertentu. Dengan menggunakan alur fikir semacam ini, maka kekerasan yang terjadi dalam lingkup rumah tangga (domestic violence) merupakan jenis kekerasan yang berbasis gender. Artinya kekerasan itu lahir disebabkan oleh perbedaan peran-peran gender yang dikontsruksi secara sosial dimana salah satu pihak menjadi subordinat dari pihak lain. Konsep gender merupakan suatu sifat yang melekat pada kaum laki-laki maupun perempuan yang di konstruksi secara sosial maupun kultural ${ }^{8}$.

\section{3) Ingkar Janji Menikah (IJM)}

Tahun 2016 pelayanan komunikasi masyarakat juga mencatat pengaduan ingkar janji menikah (IJM) sebanyak 7 (tujuh) kasus. Pelaku ingkar janji menikah memiliki latar belakang pekerjaan sebagai anggota Polisi, Pegawai Negeri Sipil dan Pegawai salah satu bank swasta.
Grafik 5. Pelayanan Komunikasi Masyarakat Kasus Ingkar Janji Menikah per Triwulan Tahun 2016

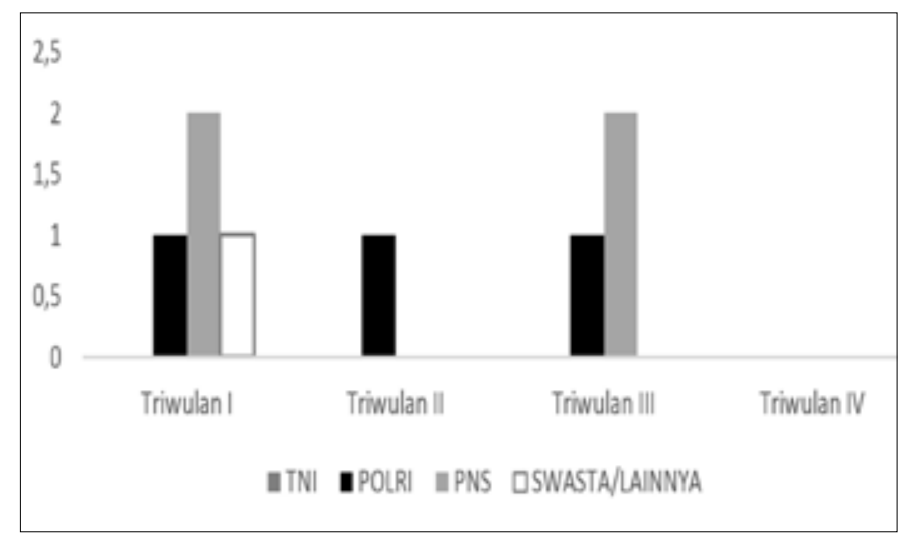

Sumber : Data Primer Kantor Wilayah Kementerian Hukum dan HAM NTT

Tindakan ingkar janji nikah ketika di bawah ke jalur hukum, saat ini seolah masih bertemu tembok kokoh karena belum memiliki payung hukum yang jelas padahal pihak perempuan telah dipermalukan baik di keluarga maupun depan umum dan juga kelangsungan kehidupan anak yang dilahirkan tanpa ayah akan dipandang sebelah mata oleh masyarakat. Jika pelaku adalah seorang Pegawai Negeri Sipil maka tindakannya tersebut bertentangan dengan Peraturan Pemerintah No. 53 Tahun 2010 tentang Disiplin Pegawai Negeri Sipil begitu pula dengan instansi lainnya, memiliki kode etik/ peraturan masing-masing.

Ingkar janji yang diucapkan oleh pihak lakilaki kepada perempuan ini tentunya sangat merugikan bagi perempuan. Apalagi dari beberapa kasus yang terjadi dalam masyarakat bahwa janji kawin ini dapat diindikasikan sebagai penyebab dari dilakukannya hubungan seks pra nikah, tetapi kabanyakan kasus ingkar janji kawin ini tidak mendapatkan penyelesaian melalui jalur hukum. Penyelesaian dengan cara 
tersebut dianggap dapat membuat hubungan seseorang dengan orang lain menjadi tidak lebih baik, ataupun proses yang melalui jalur hukum dianggap berjalan sangat lama. Komisioner Komnas Perempuan, Sri Wiyanti Eddyono, juga menilai perbuatan mengingkari janji menikahi sering terjadi namun sulit untuk diangkat ke ranah hukum. "Selama ini sulit diselesaikan secara hukum." 9

\section{4) Penganiayaan}

Kasus penganiayaan juga merupakan salah satu bentuk pelanggaran HAM, pada tahun 2016 Tim Pelayanan Komunikasi Masyarakat Kantor Wilayah Kementerian Hukum dan HAM NTT menerima 6 kasus penganiayaan yang dikomunikasikan masyarakat baik lisan maupun tertulis.

\section{Grafik 6. Pemetaan Yankomas Kasus} Penganiayaan per Triwulan Tahun 2016

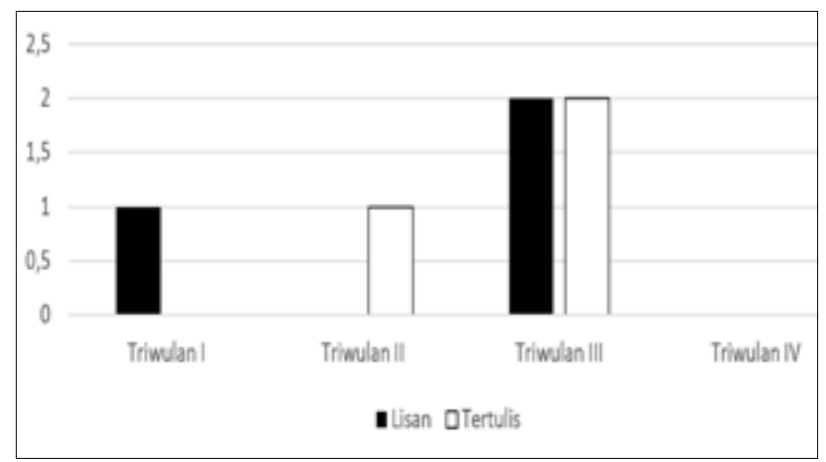

Sumber : Data Primer Kantor Wilayah Kementerian Hukum dan HAM NTT

Kasus penganiayaan yang diadukan tidak hanya dialami oleh orang dewasa namun juga dialami oleh anak-anak. Pada tahun 2016 terdapat 2 kasus penganiayaan terhadap anak dan 4 kasus penganiayaan terhadap orang dewasa.

Grafik 7. Pemetaan Yankomas Kasus Penganiayaan Anak dan Orang Dewasa per Triwulan Tahun 2016

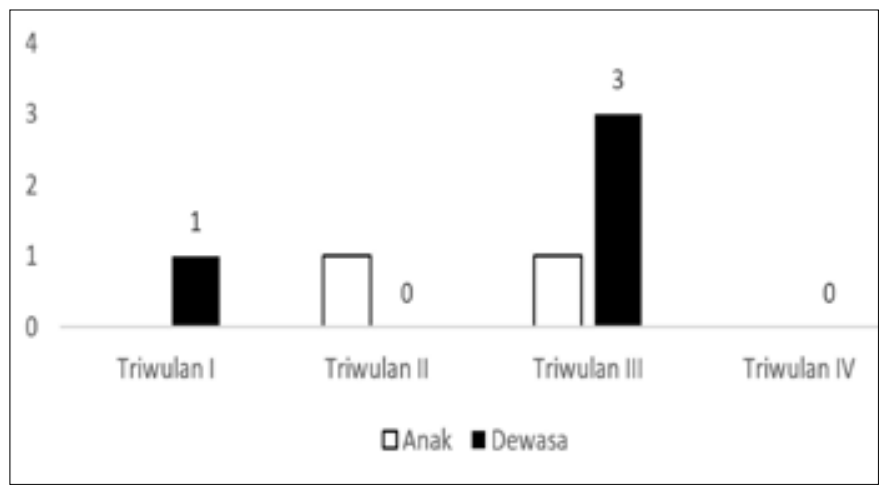

Sumber : Data Primer Kantor Wilayah Kementerian Hukum dan HAM NTT

\section{5) Ketenagakerjaan}

Pertumbuhan ekonomi yang sangat cepat ditandai dengan tumbuhnya industri-industri baru yang menimbulkan banyak peluang bagi angkatan kerja baik pria maupun wanita. Dalam hal ini hukum tentang ketenagakerjaan berkaitan dengan pelaksanaannya sangat diperlukan guna memenuhi hak-hak dan perlindungan yang mendasar bagi tenaga kerja dan pekerja atau buruh serta pada saat yang bersamaan dapat mewujudkan kondisi yang kondusif bagi pengembangan dunia usaha.

Masalah ketenagakerjaan yang dikomunikasikan kepada Tim Pelayanan Komunikasi Masyarakat Kantor Wilayah Kementerian Hukum dan HAM NTT sepanjang tahun 2016 sebanyak 3 kasus yaitu berkaitan dengan tidak dibayarkannya gaji pegawai

9 http://www.hukumonline.com/berita/baca/lt4b2a4256a32ea/tidak-menepati-janji-menikahi-adalah-pmh (diakses 20 maret 2017). 
selama 9 bulan dan pemutusan hubungan kerja oleh perusahaan.

\section{Grafik 8. Pemetaan Yankomas Kasus} Ketenagakerjaan per Triwulan Tahun 2016

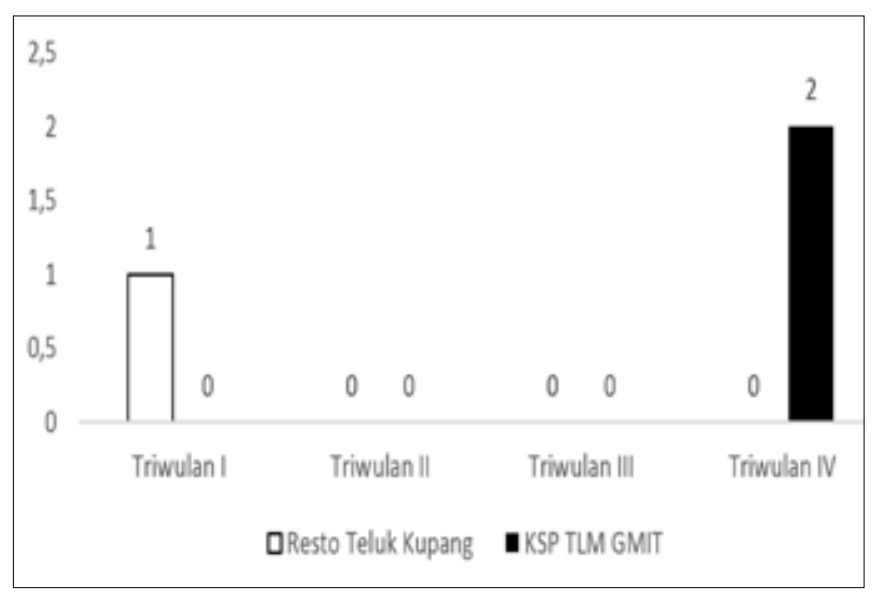

Sumber : Data Primer Kantor Wilayah Kementerian Hukum dan HAM NTT

Masalah tidak dibayarkan gaji ini dan PHK secara merupakan masalah tenaga kerja yang menyumbang angka pengganguran yang aka membuat para angkatan kerja beralih menjadi TKI/ TKW. Secara ideal sebenarnya dengan bekal pendidikan tinggi sewajarnya angkatan kerja dapat menduduki sebuah pekerjaan sesuai dengan "investasi" yang telah dikeluarkannya, setidaknya demikian menurut Teori Human Capital $^{10}$. Namun kenyataan berbicara lain pengangguran yang berpendidikan tampaknya menjadi "tren" dan sesuatu yang lazim di kalangan masyarakat dengan kedok "jual mahal" dikarenakan gaji (pertama) yang ditawarkan kurang sesuai dengan investasinya.

\section{6) Pertanahan}

Tanah merupakan kebutuhan manusia yang mendasar karena manusia hidup serta melakukan aktivitasnya diatas tanah sehingga secara langsung maupun tidak langsung manusia selalu berhubungan dengan tanah. Masalah pertanahan yang diadukan ke Tim Pelayanan Komunikasi Masyarakat pada tahun 2016 antara lain berkaitan dengan pengurusan sertifikat tanah oleh anggota masyarakat yang terlalu lama, hasil klarifikasi berkas yang besangkutan tidak lengkap sehingga pelapor diminta untuk mengecek kembali ke Kantor BPN tempat dimasukan berkas. Terdapat juga kasus konflik pertanahan yang timbul dari pengaduan suatu pihak (orang/badan) yang berisi keberatan-keberatan dan tuntutan hak atas tanah, baik terhadap status tanah, prioritas maupun kepemilikannya dengan harapan memperoleh penyelesaian secara administrasi sesuai ketentuan yang berlaku.

Grafik 9. Yankomas Kasus Pertanahan Berdasarka Jenis Laporan Tahun 2016

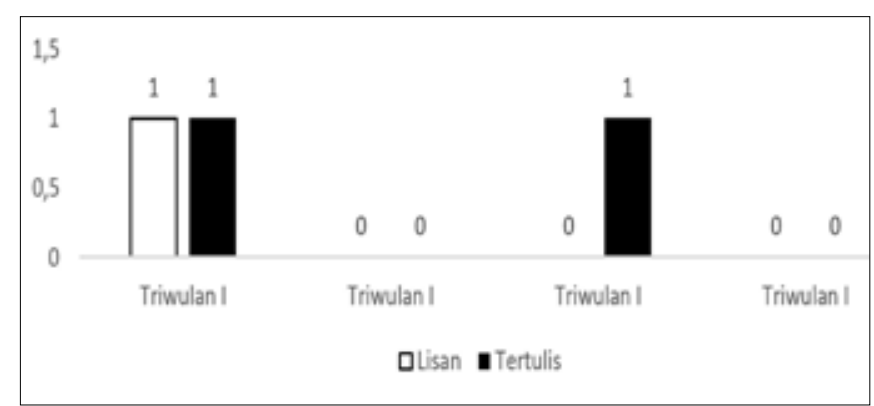

Sumber : Data Primer Kantor Wilayah Kementerian Hukum dan HAM NTT

Permasalahan pertanahan yang dikomunikasikan masyarakat kepada Tim Pelayanan Komunikasi Masyarakat pada tahun 2016 sebanyak 3 (tiga) kasus yang disampaikan secara lisan dan tertulis. Ketiga kasus yang diadukan berasal dari kabupaten yang berbeda- 
beda yaitu Kota Kupang, Kabupaten Kupang dan Kabupaten Timor Tengah Selatan (TTS).

Grafik 10. Pemetaan Yankomas Berdasarkan Asal Daerah Tahun 2016

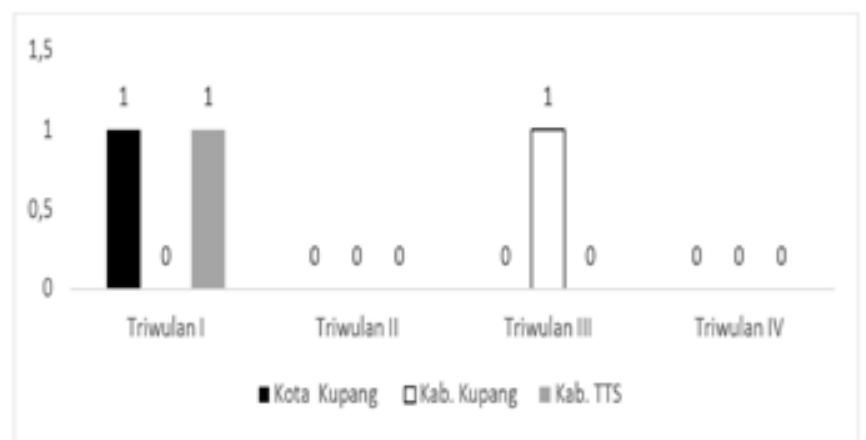

Sumber : Data Primer Kantor Wilayah Kementerian Hukum dan HAM NTT

\section{7) Hak Anak Atas Pendidikan}

Anak merupakan generasi penerus bangsa, agar suatu bangsa menjadi berkelas dunia anak harus memperoleh pendidikan yang baik. Akses pendidikan bagi anak harus terbuka, kualitas pendidikan juga hari demi hari terus ditingkatkan. Namun tidak dapat dipungkiri dalam penyelenggaraan pendidikan masih ditemui kendala dan permasalahan.

Grafik 11. Pemetaan Yankomas per Triwulan Tahun 2016

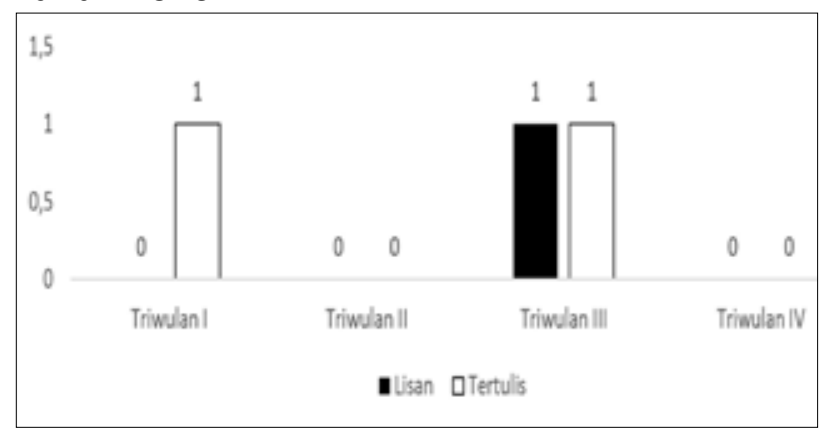

Sumber : Data Primer Kantor Wilayah Kementerian Hukum dan HAM NTT
Permasalahan hak anak atas pendidikan yang diadukan ke Tim Pelayanan Komunikasi Masyrakat di Tahun 2016 sebanyak 3 kasus yaitu berkaitan dengan pemberian ijazah yang tertunda, perbuatan orang tua yang berdampak kepada kesempatan anak untuk bersekolah, dan ketersediaan guru mata pelajaran agama. Bahwa permasalahan-permasalahan ini telah dikoordinasikan dengan Dinas Pendidikan dan Kebudayaan Provinsi NTT dan instansi terkait lainnya. Hasilnya pihak sekolah meminta siswa yang bersangkutan menghadap ke sekolah untuk mengambil ijazahnya. Masalah pendidikan dapat teratasi jika pendidikan dapat menyediakan kesempatan pemerataan belajar, artinya semua warga Negara yang butuh pendidikan dapat ditampung dalam suatu satuan pendidikan; Dapat mencapai hasil yang bermutu artinya: perencanaan, pemrosesan pendidikan dapat mencapai hasil sesuai dengan tujuan yang telah dirumuskan. Dapat terlaksana secara efisien artinya: pemrosesan pendidikan sesuai dengan rancangan dan tujuan yang ditulis dalam rancangan; Produknya yang bermutu tersebut relevan, artinya: hasil pendidikan sesuai dengan kebutuhan masyarakat dan pembangunan ${ }^{11}$. Inilah yang seharusnya dilakukan oleh Pemerintah untuk menyelesaikan masalah pendidikan.

\section{8) Pemerkosaan/Pencabulan/Kekerasan Seksual}

Kasus pemerkosaan/pencabulan/kekerasan seksual yang dikomunikasikan masyarakat kepada Tim Pelayanan Komunikasi Masyarakat Kantor Wilayah Kementerian Hukum dan HAM NTT pada tahun 2016 sebanyak 2 kasus. Kedua kasus tersebut dialami oleh anak perempuan.

11 Umar Tirtarahardja dan La Sulo. Pengantar Pendidikan. (Jakarta: PT Rineka Cipta 2005)., hal 237 
Grafik 12. Pemetaan Yankomas Kasus Pemerkosaan/Pencabulan/Kekerasan Seksual per Triwulan Tahun 2016

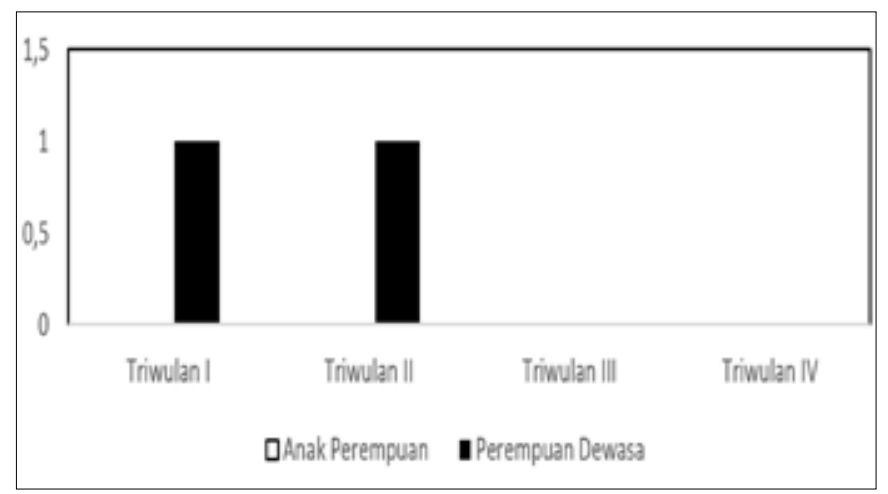

Sumber : Data Primer Kantor Wilayah Kementerian Hukum dan HAM NTT

\section{9) Penelantaran Anak (akibat cerai/IJM)}

Perbuatan orang dewasa sering berdampak kepada anak-anak, antara lain perceraian suami isteri dan ingkar janji menikah yang dilakukan orang dewasa salah satu dampaknya yaitu penelantaran terhadap anak.

Penelantaran anak akibat perceraian/ ingkar janji menikah yang dikomunikasikan ke Tim Pelayanan Komunikasi Masyarakat Kantor Wilayah Kementerian Hukum dan HAM NTT pada tahun 2016 sebanyak 2 (dua) pengaduan yaitu 1 (satu) pengaduan penelantaran anak akibat perceraian dan satu lannya penelantaran anak akibat ingkar janji menikah (IJM).
Grafik 13. Pemetaan Yankomas Kasus Penelantaran Anak per Triwulan Tahun 2016

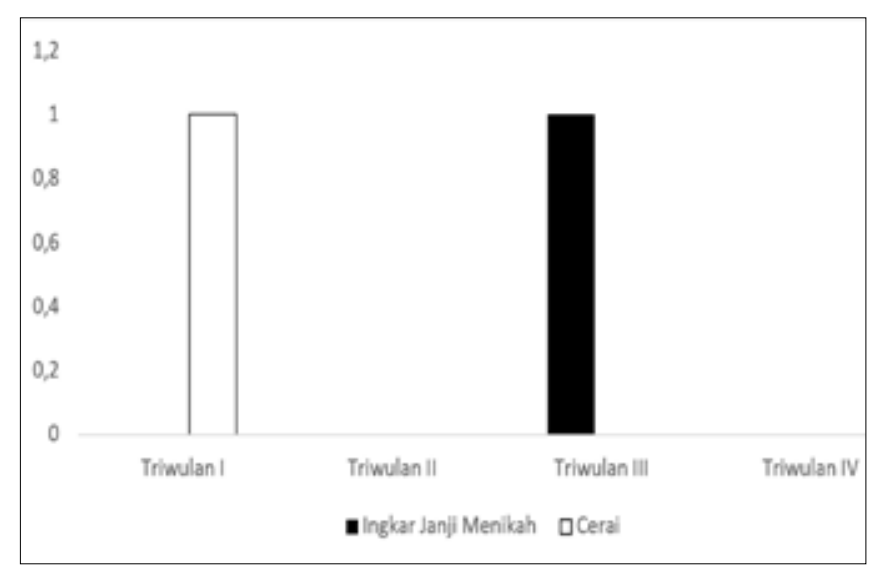

Sumber : Data Primer Kantor Wilayah Kementerian Hukum dan HAM NTT

\section{0) Kepegawaian}

Permasalahan kepegawaian berkaitan dengan status pegawai negeri sipil pada instansi pemerintah, pada tahun 2016 terdapat 2 (dua) pengaduan yang disampaikan secara lisan dan tertulis. Kedua pengaduan tersebut berasal dari Kabupaten Kupang.

Grafik 14. Pemetaan Yankomas Kasus Kepegawaian per Triwulan Tahun 2016

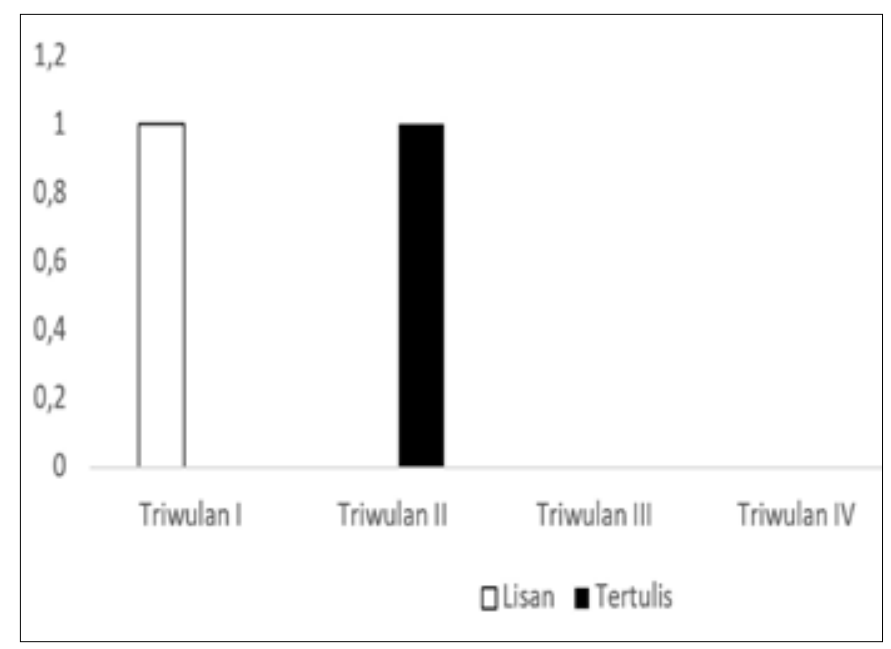

Sumber : Data Primer Kantor Wilayah Kementerian Hukum dan HAM NTT

Kinerja instansi pemerintah diukur melalui tingkat pencapaian sasaran ataupun tujuan 
instansi pemerintah sebagai penjabaran dari visi, misi dan rencana strategi instansi pemerintah yang mengindikasikan tingkat keberhasilan dan kegagalan pelaksanaan kegiatan-kegiatan sesuai dengan program dan kebijakan yang ditetapkan. Pemerintah yakin perbaikan kinerja pemerintah dapat terlaksana bila setiap instansi pemerintah menegakkan disiplin PNS. Disiplin tersebut tidak terjadi hanya untuk sementara. Penerapan peraturan disiplin PNS harus tegas dan konsisten. Selain itu diharapkan PNS wajib menjaga dan mengembangkan etika profesinya. Masalah inilah yang menyebabkan terjadi mutasi dan pemmberhentian pejabat dari jabatan yang dinyatakan oleh pegawai sebagai tindakan sewenang-wenang dari pejabat pembina kepegawaian. Mutasi sebenarnya tidak selamanya sama dengan pemindahan. Mutasi meliputi kegiatan memindahkan tenaga kerja, pengoperan tanggung jawab, pemindahan status ketenagakerjaan, dan sejenisnya. Adapun pemindahan hanya terbatas pada mengalihkan tenaga kerja dari suatu tempat ke tempat lain. Jadi, mutasi lebih luas ruang lingkupnya ketimbang pemindahan. Salah satu perwujudan kegiatan mutasi adalah pemindahan tenaga kerja dari satu tempat kerja ke tempat kerja lain $^{12}$.

\section{1)Hak Asuh, Keterangan Palsu, dan Kehutanan}

Selain permasalahan-permasalahan tersebut diatas, terdapat permasalahan hak asuh anak, keterangan palsu, dan kehutanan masingmasing sebanyak 1 (satu) kasus.
Grafik 15. Pemetaan Yankomas Kasus Hak Asuh, Keterangan Palsu, dan Kehutanan per Triwulan Tahun 2016

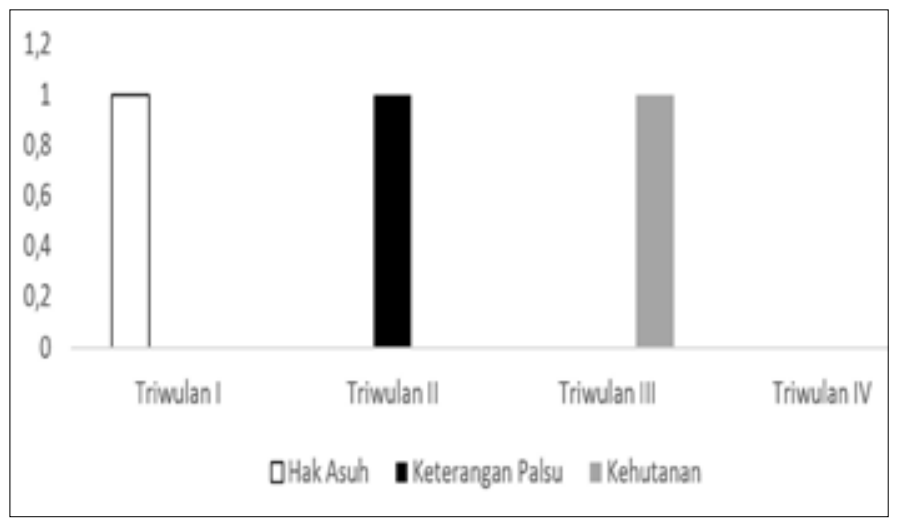

Sumber : Data Primer Kantor Wilayah Kementerian Hukum dan HAM NTT

Permasalahan ini tergolong dalam masalah lain-lain yang dikomunikasikan kepada tim yankomas dan telah dicari solusi penyelesaiannya.

\section{Penutup}

Pelayanan Komunikasi Masayarakat atau yang dikenal dengan yankomas merupakan sarana untuk menyelesaikan dugaan pelanggaran HAM yang terjadi di masyarakat yang dimandatkan oleh Peraturan Presiden 23 Tahun 2011 tentang Rencana Aksi Hak Asasi Manusia tahun 2011-2014. Pada tahun 2016 terdapat 50 (lima puluh) permasalahan yang dikomunikasikan kepada Tim Pelayanan Komunikasi Masyarakat yaitu 25 pengaduan lisan/konsultasi dan 25 pengaduan secara tertulis. Pada Triwulan I terdapat 21 pengaduan, Triwulan II sebanyak 6 pengaduan, Triwulan III sebanyak 14 pengaduan dan Triwulan IV sebanyak 8 pengaduan baik tertulis maupun lisan. Semua masalah ini

12 Pramata Bayu Putra Melodica, "Mutasi Dan Rotasi Merupakan Fenomena Yang Biasa Terjadi Di Sebuah Organisasi", hlm. 10. 
diselesaikan dengan baik Pelayanan Komunikasi Masyarakat hendaknya terus dikembangkan melalui sosialisasi melalui media sarana dan prasarana mengingat tingginya angka pengaduan masyarakat yang mulai mencari menyadari bahwa terdapat peran negara untuk melakukan perlindungan,pemajuan penegakan Hak Asasi Manusia

\section{Daftar Pustaka}

\section{Buku}

Ananta, Aris, Ciri demografis kualitas penduduk dan pembangunan ekonomi, (Jakarta: Lembaga Demografi dan Lembaga Penelitian Fakultas Ekonomi Universitas Indonesia, 1993)

Fakih, Mansour, Analisis Gender dan Transformasi Sosial, (Yogyakarta: Pustaka Pelajar, 2003)

Ibrahim, Johnny, Teori dan Metodologi Penelitian Hukum Normatif, (Surabaya: Bayumedia Publishing, 2006)
Syahuri, Taufiqurrohman, Hukum Konstitusi: Proses dan Prosedur Perubahan UUD di Indonesia 1945 2002. (Bogor: Ghalia Indonesia, 2004)

Tirtarahardja, Umar, dan La Sulo. Pengantar Pendidikan, (Jakarta: PT Rineka Cipta 2005)

\section{Internet}

http://www.hukumonline.com/berita/baca/ It4b2a4256a32ea/tidak-menepati-janjimenikahi-adalah-pmh (diakses 20 Maret 2017)

Ramli Taka Wanokrok: Melunturkan arogansi aparat http:/sarubanglahaping. blogspot.co.id/ 2016/08/senjata-dan-arogansi.html (diakses 20 Maret 2017)

\section{Peraturan}

Undang- Undang Nomor 39 Tahun 1999 tentang Hak Asasi Manusia

Peraturan Presiden Nomor 75 Tahun 2015 tentang Rencana Aksi Nasional Hak Asasi Manusia 20152019

Peraturan Menteri Hukum dan HAM Nomor 23 Tahun 2013 tentang Pedoman Pelayanan Komunikasi Masyarakat Rencana Aksi Nasional Hak Asasi Manusia

54 Kompas.Com, "Gugatan Sedikit, Benarkah Kesadaran Berdemokrasi di Indonesia Meningkat", http://pilkada. kompas.com/read/2016/03/10/06262261/Gugatan.Sedikit.Benarkah.Kesadaran.Berdemokrasi.di.Indonesia. Meningkat. (diakses 11 Maret 2016). 